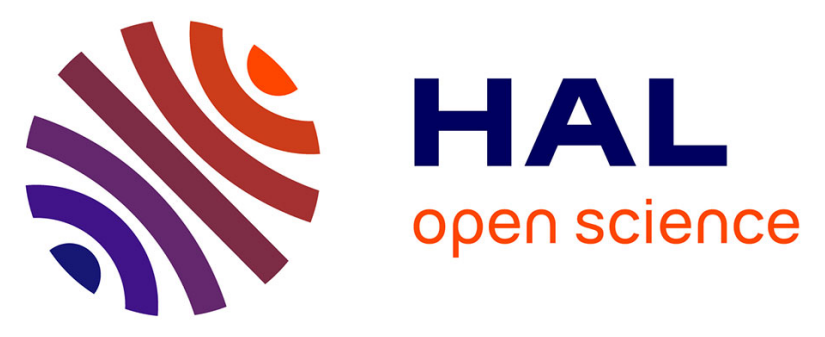

\title{
Identifying the Earliest Neolithic Settlements in the Southeastern Balkans
}

\author{
Laurent Lespez, Zoï Tsirtsoni, Pascal Darcque, Dimitra Malamidou, \\ Koukouli-Chrysanthaki Chaido, Arthur Glais
}

\section{To cite this version:}

Laurent Lespez, Zoï Tsirtsoni, Pascal Darcque, Dimitra Malamidou, Koukouli-Chrysanthaki Chaido, et al.. Identifying the Earliest Neolithic Settlements in the Southeastern Balkans: Methodological Considerations Based on the Recent Geoarchaeological Investigations at Dikili Tash (Greek Eastern Macedonia). Reingruber Agathe; Tsirtsoni Zoï; Nedelcheva Petranka. Going West? The Dissemination of Neolithic Innovations between the Bosporus and the Carpathians, Proceedings of the EAA Conference, Istanbul, 11 September 2014, 3, Routledge, p. 43-55, 2017, Themes in Contemporary Archaeology, 978-1-138-71483-0. hal-02639696

\section{HAL Id: hal-02639696 \\ https://hal.parisnanterre.fr/hal-02639696}

Submitted on 28 May 2020

HAL is a multi-disciplinary open access archive for the deposit and dissemination of scientific research documents, whether they are published or not. The documents may come from teaching and research institutions in France or abroad, or from public or private research centers.
L'archive ouverte pluridisciplinaire HAL, est destinée au dépôt et à la diffusion de documents scientifiques de niveau recherche, publiés ou non, émanant des établissements d'enseignement et de recherche français ou étrangers, des laboratoires publics ou privés. 


\title{
Going West? \\ The Dissemination of Neolithic Innovations between the Bosporus and the Carpathians
}

\author{
Proceedings of the EAA Conference, Istanbul, 11 September 2014 \\ Edited by Agathe Reingruber, Zoï Tsirtsoni, Petranka Nedelcheva
}

Going West? uses the latest data to question how the Neolithic way of life was diffused from the Near East to Europe via Anatolia. The transformations of the 7th millennium BC in western Anatolia undoubtedly had a significant impact on the neighbouring regions of southeast Europe. Yet the nature, pace and trajectory of this impact needs still to be clarified. Archaeologists previously searched for similarities in prehistoric, especially Early Neolithic material cultures on both sides of the Sea of Marmara. Recent research shows that although the isthmi of the Dardanelles and the Bosporus connect Asia Minor and the eastern Balkans, they apparently did not serve as passageways for the dissemination of Neolithic innovations. Instead, the first permanent settlements are situated near the Aegean coast of Thrace and Macedonia, often occurring close to the mouths of big rivers in secluded bays. The courses and the valleys of rivers such as the Maritsa, Strymon and Axios were perfect corridors for contact and exchange not only in a south-north direction but also the other way round. Using previous studies as a basis for fresh research, this volume presents exciting new viewpoints by analyzing recently discovered materials and by applying modern research methods of interdisciplinary investigations.

The seventeen authors of this book have dedicated their research to a renewed evaluation of an old problem: namely, the question of how the complex transformations at the transition from the Mesolithic to the Neolithic can be explained. They have focused their studies on the vast area of the eastern Balkans and the Pontic region between the Bosporus and the rivers Strymon, Danube and Dniestr. Going West? thus offers an overview of the current state of research concerning the Neolithisation of these areas, considering varied viewpoints and also providing useful starting points for future investigations.

Agathe Reingruber, researcher at the Freie Universität Berlin, is specialized on topics related to the Neolithic and Chalcolithic of southeast Europe (Greece, Turkey, Romania). She is currently running a project in northeastern Thessaly focusing on population dynamics.

Zoï Tsirtsoni, researcher at the French National Centre of Scientific Research (CNRS, Laboratory Archéologies et Sciences de l'Antiquité, Nanterre), is specialized on the Neolithic, Chalcolithic and Bronze Age periods in the Aegean and southern Balkans. She is co-director of the Greek-French research project at the multilayer (tell) settlement of Dikili Tash in northern Greece.

Petranka Nedelcheva, Assistant Professor at the New Bulgarian University (Sofia), is a lithics specialist for the Neolithic, Chalcolithic and Bronze Age periods in southeast Europe, western Anatolia and the Caucasus. She participates in several projects in Greece, Turkey, Romania and Georgia. 


\title{
Identifying the Earliest Neolithic Settlements in the Southeastern Balkans Methodological Considerations Based on the Recent Geoarchaeological Investigations at Dikili Tash (Greek Eastern Macedonia)
}

\author{
Laurent Lespez, Zoï Tsirtsoni, Pascal Darceue, Dimitra Malamidou, \\ Haïdo Koukouli-Chryssanthaki and Arthur Glais
}

\begin{abstract}
INTRODUCTION
For many decades the difficulty to locate sites with permanent installations datable to the 7 th millennium $\mathrm{BC}$ in the area immediately west of the Bosporus (Thrace and eastern Macedonia: Figure 4.1) has nourished the idea that this part of Europe entered the sedentary way of life later than its neighbours, namely later than the rest of Greece (Demoule \& Perlès, 1993: 365, 388; Andreou et al., 1996: 586; Perlès, 2001: 59-60). This premise, which has been maintained even after the discovery of such early layers at Hoca Çeşme, at the mouth of the Maritsa/Meriç/Evros River (Özdogan, 1993, 1997; see also Karul, this volume), has been further used in several models about the Neolithic expansion throughout Europe. The latter put forward the existence of presumed stopping places that coincided with the topographical, ecological or agro-ecological barriers met by the first settlers (Van Andel \& Runnels, 1995: 494-8; Guilaine, 2001; Rasse, 2008; Özdoğan, 2011a, 2011b; Guilaine, 2012: 10), and acted as 'centres of renewed expansion' (Bocquet-Appel et al., 2009; see also syntheses by Reingruber, 2011; Vander Linden, 2011). In this chapter we present evidence that contradicts this claim, while at the same time raising questions about the limits to the conclusions based on standard archaeological investigations (survey and digging) and suggesting supplementary tools for overcoming the biases.
\end{abstract}

\section{STATE OF THE Questions}

In the specific area of the Greek eastern Macedonia, the delay of the start of the Neolithic seemed even longer than in Thrace, as no site was known, not only for the late 7th millennium Bc, but for the early 6th millennium $\mathrm{BC}$ as well. Indeed, with the exception of a few dubious white-on-red painted sherds from Toumba
Serron (Grammenos \& Fotiadis, 1980: 17, 20-3), no site had yielded surface finds that could be attributed to the Early Neolithic period as defined for the Aegean (Alram-Stern, 1996: 88-9; Andreou et al., 1996: 538; Treuil et al., 2008: 58-9). All recognisable artefacts from surface collections were assigned to phases contemporaneous with the Thessalian 'pre-Dimini' stages (Tsangli, Arapi), or later (Grammenos \& Fotiadis, 1980; Grammenos, 1991: 99-105, 120-6; Koukouli et al., 2008: 397-403). Furthermore, the unique major site where excavation reached the virgin soil, the tell of Sitagroi, seemed to start towards $5500 \mathrm{cal} \mathrm{BC}$ (Renfrew et al., 1986: 175-81, 27: table 2.1), that is at a stage parallel to the very end of the Thessalian Middle Neolithic Sesklo culture and the transition to the Late Neolithic. This date was sustained also by later excavations at the neighbouring tell of Dimitra (Grammenos, 1991: 45-6) and at the insular site of Limenaria on Thasos (Papadopoulos \& Malamidou, 2012: 38-9, 282), which also reached the natural soil (see also Papadopoulos, 2009: 51-2).

Both of these arguments - the argument of surface finds and that of the lowest excavated levels - should be considered, however, with great caution. The idea that the artefacts scattered on the ground at the top of an ancient site would represent the entirety of its occupation sequence is indeed highly contested (Bintliff et al., 1999), despite some objections about the general character of the phenomenon (Mee \& Cavanagh, 2000; Davis, 2004). The representation, in particular, of the earliest occupation levels in the surface material seems even more problematic at sites with a strong sedimentation, whether the latter results from human activities (multi-layered settlements) or from natural factors (alluviation). ${ }^{1}$ In Greek eastern Macedonia, like in the

\footnotetext{
${ }^{1} \mathrm{~A}$ good example has been recently presented by Dr. St. Chryssoulaki at the International Conference about Athens and Attica in Prehistory (Athens, ASCA, 27-31 May 2015): a well-preserved Early Bronze Age settlement discovered near the riverbed of Kifissos, beneath $7 \mathrm{~m}$ of alluvial deposits. The excavation did not manage to continue below this level.
} 


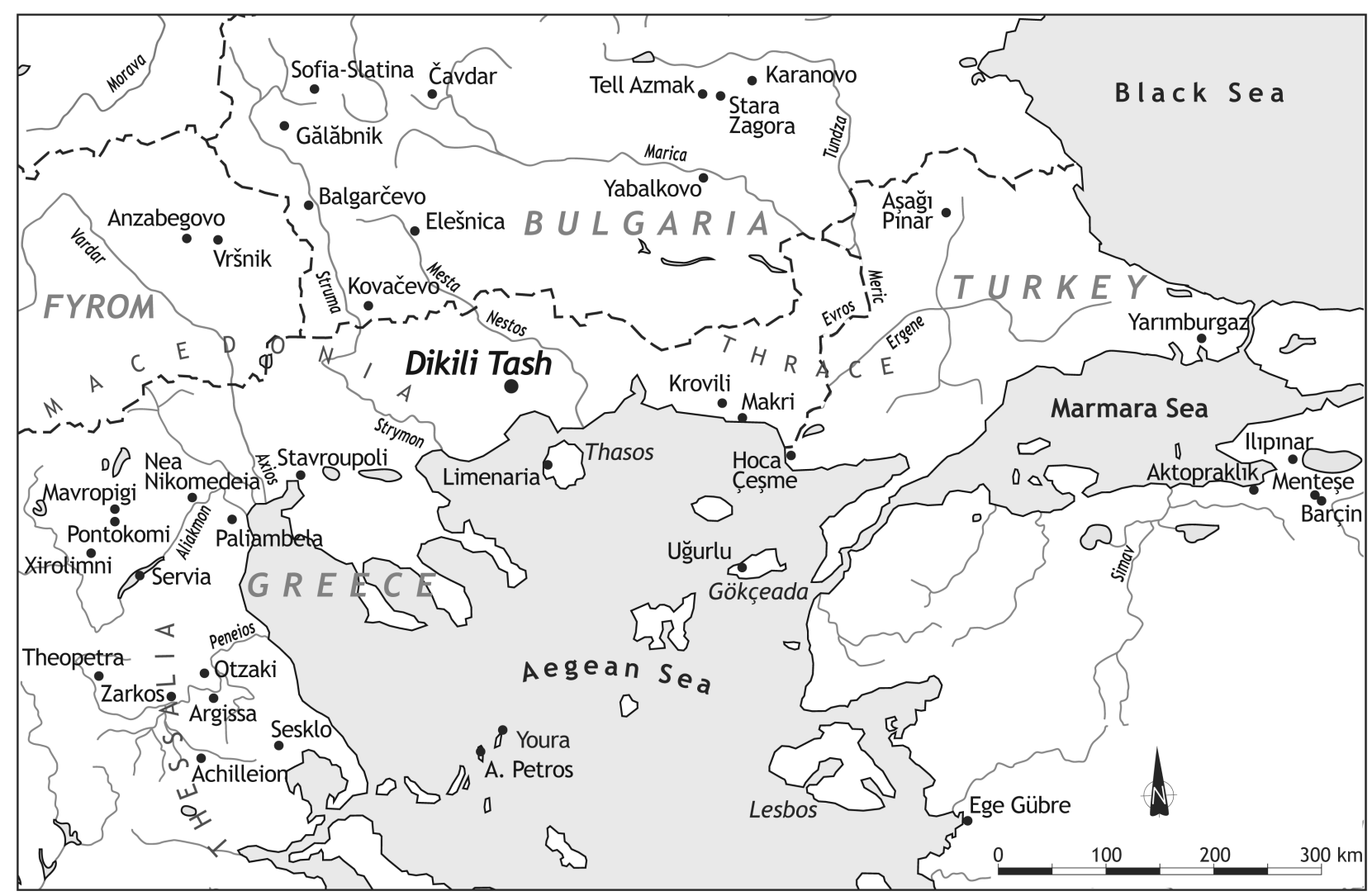

Figure 4.1. Map of the Southeastern Balkans With Neolithic Sites of the 7th and Early 6th Millennium BC. Dikili Tash Is Shown In Bold.

rest of southeast Europe, most Neolithic settlements identified so far are tell sites - a situation that reflects prehistoric settlement pattern as well as the orientation of archaeological research (Gaul, 1948; Grammenos, 1996; Bailey, 2000). On the other hand, the large plains of eastern Macedonia have undergone important alluvial, lake and marshy sedimentation during the Holocene. As demonstrated, in the lower Strymon valley, Late Neolithic sites are covered by more than $7 \mathrm{~m}$ of sedimentation (Lespez et al., 2014). We can therefore assume that many flat or low-elevated settlements have been neglected in non-systematic surface surveys, or have been buried on the edge of the alluvial plains between the Bosporus and western Macedonia.

In the case of tell sites, we are also facing the problem of the extent of the lowest excavated levels. In most cases indeed, these are only explored in just one or two very small trenches - again because of the great thickness of the overlying deposits, which does not allow extensive exposure, unless by accident (public works, looting, etc.). Thus, our knowledge about the presumed start of occupation at Sitagroi towards 5500 cal BC relies on the results of a unique 9-square-metre trench opened approximately in the centre of the tell (deep sounding ZA: Renfrew et al., 1986: 17-8 and Fig. 2.2); this applies much the same for Dimitra and Limenaria (supra). Considering that the first installations were probably smaller than the later Neolithic and Bronze Age settlements (cf. for instance Knossos: Evans, 1971: pl. VI), one might presume that they could also well be located at some other part of the perimeter of the future tell, or even beyond it.

This claim was supported by results from recent investigations at the mound of Krovyli in the neighbouring area of Aegean Thrace, using core-drills into the natural soil (Ammerman et al., 2008). The earliest radiocarbon-dated level here (first half of 6th millennium $\mathrm{BC}$ at about $40 \mathrm{~cm}$ above the natural palaeosol) was recorded not in the centre, but near the eastern edge of the mound (core 2: see Ammerman et al., 2008: 143-4, Fig. 2), although it is not entirely clear whether this was due to a lack of adequate organic samples or a lack of deposits in the other cores.

Our own research in the years after 2010 on and around the tell settlement of Dikili Tash, in the southeastern part of the Drama-Philippi plain, goes further in this direction: it proves indeed that part of the current archaeological picture and the discourse that accompanies it are seriously biased by taphonomical problems. Using this experience as a starting point, we plead here for a closer collaboration between archaeologists and geomorphologists, and we propose an entire 
range of analytical procedures (in the field and in the laboratory), which could help remedy this problem. More than just filling the gap in the regional distribution maps, this knowledge should provide the necessary framework for any discussions about the conditions and the pace of the spread of the Neolithic way of life into the Balkans. Some of the results have been already presented elsewhere (Darcque, 2013: 69-72; Lespez et al., 2013; Darcque et al., 2014), but others are discussed here for the first time.

\section{The Framework of Research at Dikili Tash}

The site of Dikili Tash is rather well known in the archaeological literature; therefore, it does not seem necessary to proceed here with a detailed presentation (a full, up-to-date bibliography is given at www.dikilitash.fr; see also references cited above and below). Three points should be recalled however, which are relevant to our topic.

The first point is the topographical situation of the site: at the foot of a low mountain range (Lekani), originally covered by forests, right next to an important freshwater spring and close to the lowest parts of an intra-mountainous floodplain covered by water (swamp) during the entire Holocene period (Treuil, 1992: 3-11; Lespez et al., 2000: 415-7; Lespez, 2008: 260-7). This privileged location had obviously favoured human settlement in all periods from the mid-6th millennium $\mathrm{BC}$ onwards, that is the periods attested by levels excavated archaeologically (Darcque \& Tsirtsoni, 2010), and legitimated the assumption that the site might have attracted also earlier populations, including those first adopting a sedentary way of life.

The second point concerns the state of archaeological research prior to the investigations that we discuss here (i.e. prior to 2010). Excavations at the tell, whose top lies today at about $15 \mathrm{~m}$ from the surrounding surface, proceeded generally in a step-like manner, with lower trenches starting approximately at the point where those located higher - in terms of both hypsometer and relative chronology - stopped. Thus there existed no unique 'deep' stratigraphic trench like that in Sitagroi (supra), but several 'medium-depth' trenches starting from various altitudes and cutting through different parts of the tell's deposits. The trench that seemed to get closer to the start of the settlement was sector 1 , pursuing the older 'AA28 trench' on the southern slope of the tell (Treuil, 1992: 15, 20-1; Darcque \& Tsirtsoni, 2010: 59). The excavation had stopped there at about $4 \mathrm{~m}$ above the estimated natural soil level (based on a series of core-drills made in and around the tell in 1993: Lespez et al., 2000: 417-21), inside a destruction level of the early LN I period (c.5400/5300 cal BC). Another trench made lower in the southern slope (sector 2) got even closer to the virgin soil in terms of hypsometer, but the excavated deposits were mostly composed of later features and colluvia, suggesting that here we were at the limits or even outside of the settlement properly speaking (Darcque et al., 1990: 877; Darcque et al., 1992: 715; Darcque et al., 2009: 532-33).

The third and last point deals with evidence, or rather non-evidence, from surface finds. Indeed, one century after the site's first identification by surface collection (Welch, 1918-1919), followed by fifty years of agricultural exploitation and another fifty years of systematic archaeological investigation (Darcque, 2013; Treuil, 2014), with all the circulation, deposition and reworking of sediments that these activities involve, we knew no more than two (!) potentially Early to Middle Neolithic sherds from Dikili Tash - one with white-on-red painted decoration assigned to the horizon of Karanovo I-Kremikovci (Deshayes, 1970: 808 and Fig. 19), and one with channelled decoration assigned to Karanovo II (Deshayes, 1973: 472-3, Fig. 13). This absence of earlier material contrasted sharply with the overall estimated tell's sequence as was established from the two intra-site drills of 1993 (supra): the latter not only showed, as we said, that there existed several meters of unexplored archaeological deposits at the base of the tell, but also provided a series of very promising radiocarbon dates in the early 6th millennium BC, and even one from the mid-7th millennium $\mathrm{BC}$ (mentioned by Lespez et al., 2013: 33; see also infra).

Therefore, the two main questions that needed to be answered concerned:

(1) The date of the first settlement at Dikili Tash;

(2) The precise location of the earliest levels; concretely, we wished to know whether we could reach them by continuing down the sector 1 (i.e. by excavating the $4 \mathrm{~m}$ left to the virgin soil, which would be the most economical solution in terms of both time and effort), or if we had to look elsewhere.

In order to answer to these questions, it was decided to make a new series of core-drillings, not only to the south but also at the other sides of the tell, east, northeast and northwest, the last two being until then 'terrae incognitae'.

\section{The 2010-2013 GeOARCHAEOLOGICAL RESEARCh: METHODOLOGY}

The four main drillings made in 2010 (C1 to C4, depth from 6 to $10 \mathrm{~m}$ ) were set in the tell as shown in Figure 4.2. Two smaller drillings (depth 1 to $3 \mathrm{~m}$ ) 


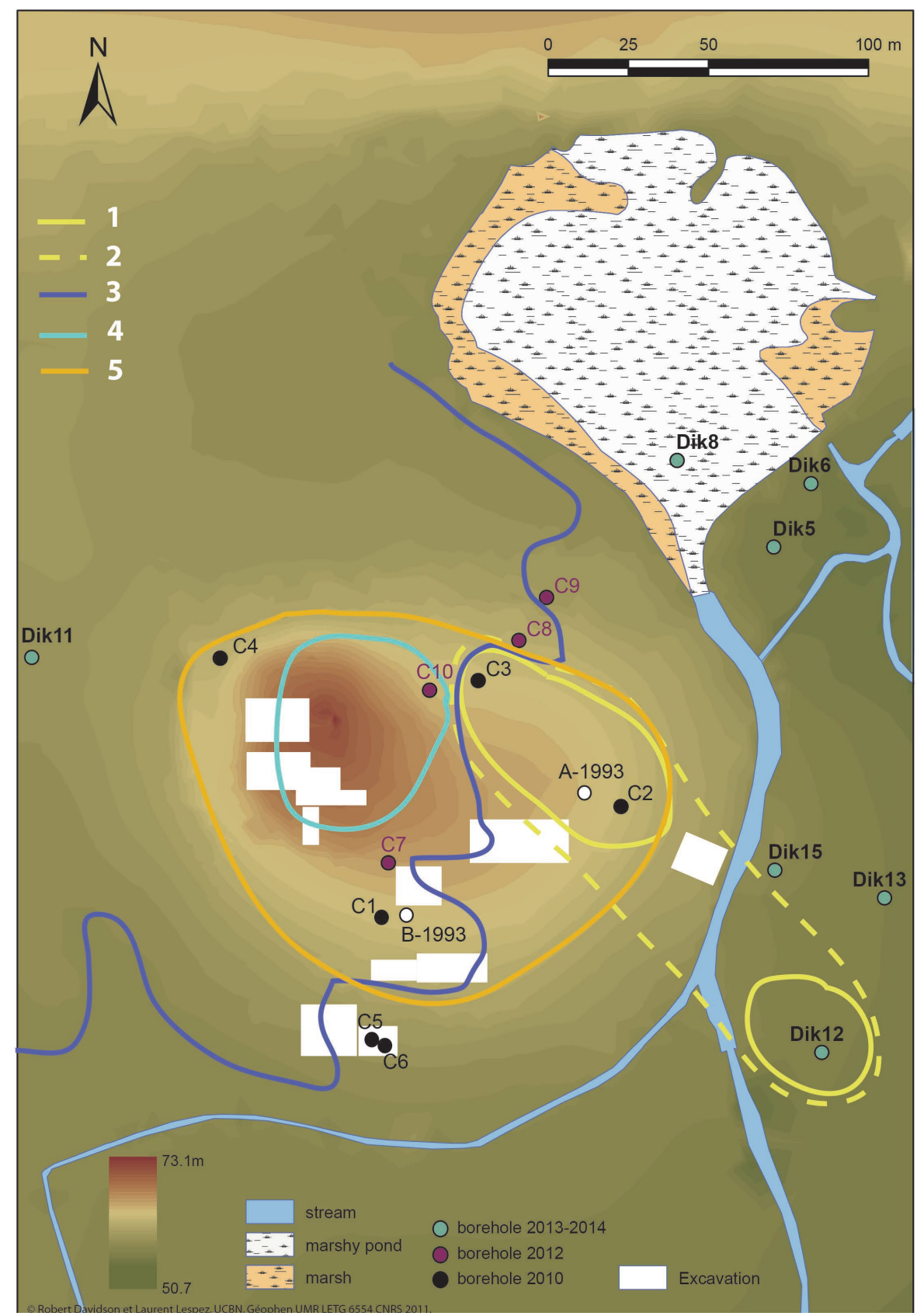

Figure 4.2. Map of the Core Drillings and Interpretation of the Settlement Dynamics During the Early Stages of the Neolithic. 1. First phase of Occupation (c.6500-6200 BC) on top of the Holocene Palaeosol. 2. Possible Extension of the Initial Settlement. 3. Limit of the Marshy and Alluvial Deposits During the Cold and Wet Period Around 6100-6200 BC. 4. Possible Extension of the Settlement During the Wet Phase, Assessed Only in core C10.

were made inside the limits of sector 2 (supra), in order to clarify the depositional sequence there. They were completed in 2012 by four additional intra-site cores (C7 to C10), whose aim was to further refine the overall occupational sequence and suggest more firmly the place where we should dig in order to reach the earliest levels with the less possible effort. Finally, a series of six drillings (Dik1 to Dik11, depth from 3 to $5.5 \mathrm{~m}$ ) was made in 2013 in the immediate surroundings of the tell, in order to investigate further the relationship between the settlement and the nearby wet zones, namely the extended Philippi marsh to the south and the small pond formed by the Dikili Tash water source to the north; further sampling in these off-site areas was made in 2014.

All drillings were realised with a hand-driven percussion device (Cobra TT) equipped with gouges of $60 \mathrm{~mm}$ diameter and $1 \mathrm{~m}$ long; work in 2012 and 2013 was facilitated by the use of a small hydraulic extractor (Figure 4.3). This kind of device seems better adapted for coring in anthropogenic layers than devices driven by heavy machinery, which tend to compact too much 


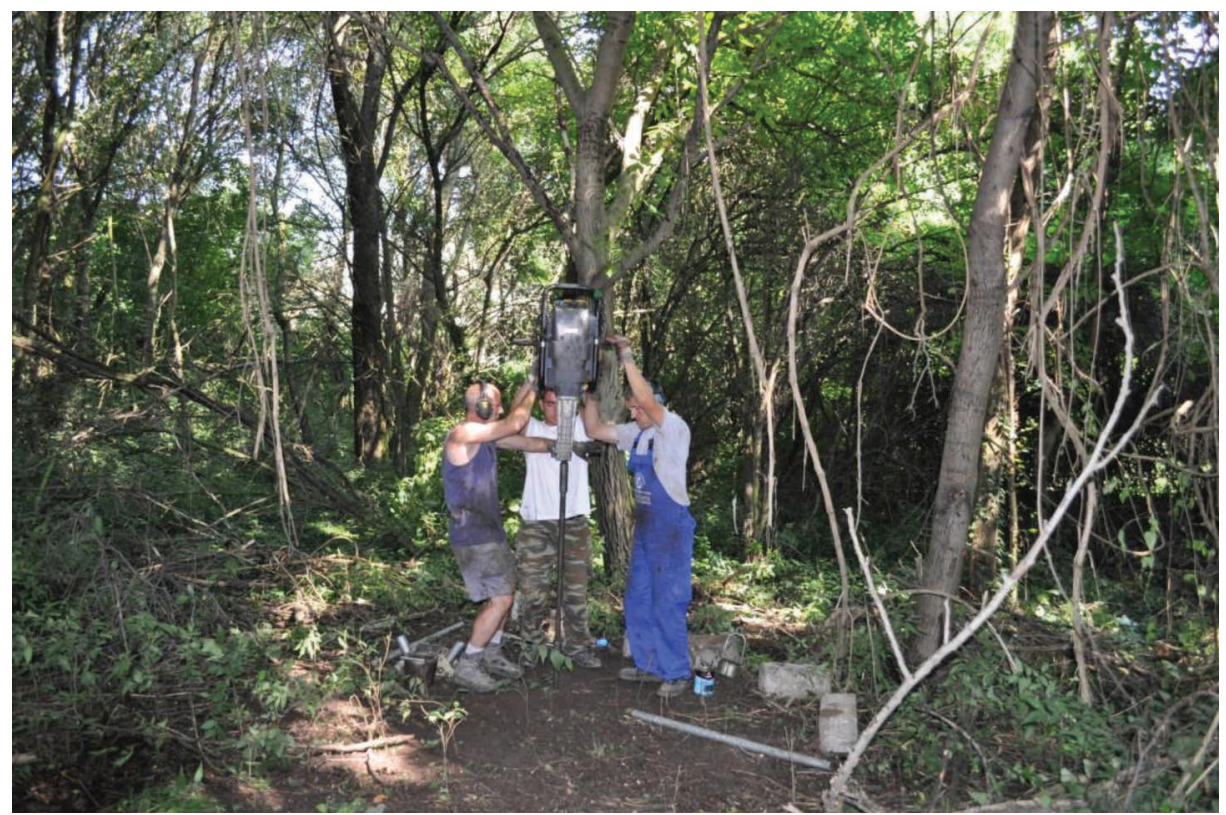

Figure 4.3. Core Drilling C10

the relatively loose sediments and to disturb more deeply the deposits.

Practically all intra-site cores and most of those made off-site (Dik6, Dik7, Dik10, Dik11) were taken with the open gouge method. In this method, the sediment is carefully extracted from the gouge after each entry and is immediately described and sampled, jointly by the archaeologist and the geomorphologist (Figure 4.4). Compared to the alternative method of cores extracted in sealed opaque plastic tubes and opened later in the laboratory, this one has the advantage of providing right away a view of the aspect and content of the cores (consistency and nature of sediments, presence of artefacts, charcoal, etc.), thus presenting the possibility to adjust the research strategy accordingly (e.g. continue deeper or stop, to repeat the drilling with different equipment, to take or not take samples for ${ }^{14} \mathrm{C}$ dating). It is, however, less well adapted to a fine study of sensitive palaeobiological indicators (pollens, phytoliths, charcoal micro-remains, etc.). For this reason we also used sealed tubes for the lower part of one intra-site core (C9), as well as for two cores offsite (Dik5, Dik8) that were closer to the water source and therefore were susceptible to contain more such material, especially pollen.

The fact that the cores passed through the entire depth of the tells's thick sedimentation allowed us to develop considerably our understanding of the types of sediments met, based on the prior good knowledge of the geomorphological context of the settlement, and on that of the anthropogenic layers acquired by the archaeologists during the recent excavation programs. We took also into account the guidelines provided in reference books for the detailed description of anthropogenic sediments on the basis of micromorphological analyses (Courty et al., 1989; Courty \& Fedoroff, 2002). This combination of sedimentological and archaeological criteria allowed the distinction of several types of sediments ('faciès'), seventeen in all (Table 4.1), ranging from those with little or no human presence (F1-F7) to those which are unquestionably anthropogenic (F8F17). The number of types of sediment gives an idea of the variety of factors commanding the final aspect and consistency of the archaeological layers that form a tell.

Samples for ${ }^{14} \mathrm{C}$ dating were taken from all layers that might be of interest for understanding the stratigraphical sequence, especially in the lowest parts. We preferred, of course, occupation layers in situ or only slightly disturbed, which were by chance those containing numerous organic remains, that is charcoal or, as an exception, seeds and bones. The samples were given for dating without any prior determination of species. This choice creates some problems for interpreting the results from charcoal samples, as we are unable to say whether the provided date concerns a short-lived organism and therefore contemporary with the observed sedimentary event, or a long-lived one that could have already been old when it was trapped in the sediment. We decided, however, to take the risk, in order to accelerate the dating process, as we estimated that the probability to fall constantly on parts from the innermost rings of multi-centenary oaks was altogether weak. In the off-site cores we also dated samples from the sediment itself (organic-rich), but these results are out of the scope of the present chapter and are not discussed here. The processing was made at the Centre for Radiocarbon Dating in Lyon (France) and the measurement at the Laboratory of Carbon-14 Measurement at the 


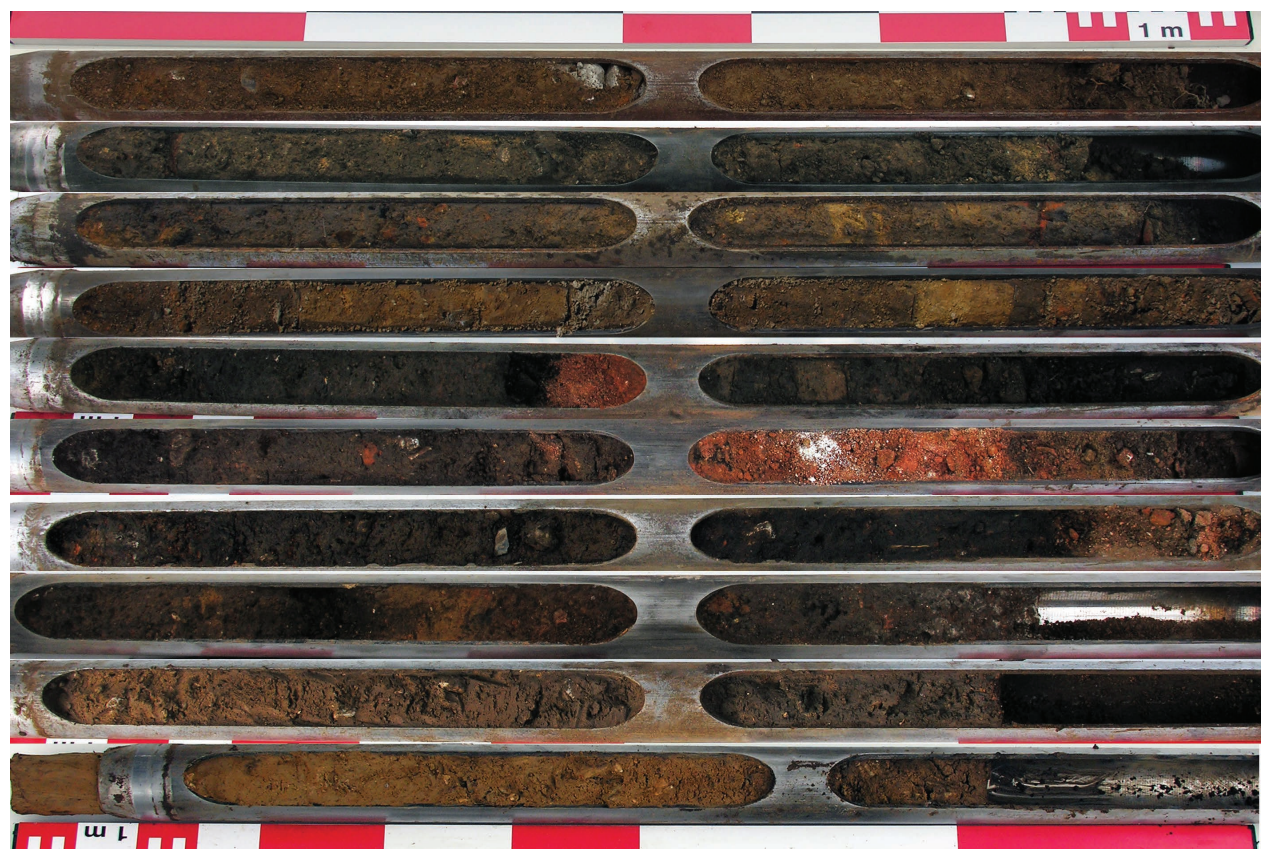

Figure 4.4. Assemblage of the Successive Parts of Core C1, Taken With the Open-Gouge Method

Table 4.1 Types of Sediments Identified in the Dikili Tash Cores

\begin{tabular}{|c|c|c|c|c|c|c|c|}
\hline Type & Organisation & Sediments & $\begin{array}{l}\text { Archaeological } \\
\text { artefacts }\end{array}$ & Nature & Process of deposits & $\begin{array}{l}\text { Post-depositional } \\
\text { evolution }\end{array}$ & Interpretation \\
\hline F1 & $\begin{array}{l}\text { Coarse } \\
\text { bedding }\end{array}$ & $\begin{array}{l}\text { Sand and } \\
\text { gravel }\end{array}$ & - & & Channel deposits & Pedogenesis & $\begin{array}{l}\text { Channel on the } \\
\text { Pleistocene alluvial fan }\end{array}$ \\
\hline F2 & $\begin{array}{l}\text { Coarse } \\
\text { bedding }\end{array}$ & $\begin{array}{l}\text { Yellowish } \\
\text { sandy silts } \\
\text { with gravel }\end{array}$ & - & & Overbank deposits & Pedogenesis & Pleistocene alluvial fan \\
\hline F3 & Massif & Yellowish silt & - & & Aeolian to colluvial & Pedogenesis & $\begin{array}{l}\text { Aeolian silt reworked } \\
\text { locally }\end{array}$ \\
\hline F4 & Aggregate & Brown silt & - & & - & Pedogenesis & Bt illuvial horizon \\
\hline F5 & Massif & $\begin{array}{l}\text { Dark grey or } \\
\text { brown silt }\end{array}$ & - & & Runoff & $\begin{array}{l}\text { Slight pedogenesis } \\
\text { Hydromorphic } \\
\text { features }\end{array}$ & Palustrine deposits \\
\hline F6 & Bedded & $\begin{array}{l}\text { Oncolithic } \\
\text { sand }\end{array}$ & + & & Runoff & Slight pedogenesis & $\begin{array}{l}\text { Carbonated alluvial } \\
\text { deposits linked to the } \\
\text { karstic stream }\end{array}$ \\
\hline F7 & Massif & $\begin{array}{l}\text { Ochre silty } \\
\text { sand }\end{array}$ & + & & Particulate & - & Foxhole \\
\hline F8 & $\begin{array}{l}\text { Thick horizon } \\
(>20 \mathrm{~cm})+ \\
\text { aggregates }\end{array}$ & $\begin{array}{l}\text { Dark brown } \\
\text { silt }\end{array}$ & ++ & $\begin{array}{l}\text { Charcoal, bone } \\
\text { fragments, burnt clay }\end{array}$ & & Erosion & $\begin{array}{l}\text { Top of palaeosol with } \\
\text { anthropogenic features }\end{array}$ \\
\hline F9 & $\begin{array}{l}\text { Thin layer } \\
(<10 \mathrm{~cm}) \\
+ \text { aggregates }\end{array}$ & $\begin{array}{l}\text { Dark brown } \\
\text { silt }\end{array}$ & ++ & $\begin{array}{l}\text { Charcoal, bone } \\
\text { fragments, burnt clay }\end{array}$ & & Erosion & $\begin{array}{l}\text { Thin soil indicating an } \\
\text { abandonment }\end{array}$ \\
\hline F10 & Random & $\begin{array}{l}\text { Light brown } \\
\text { sandy silt }\end{array}$ & ++ & $\begin{array}{l}\text { Charcoal, bone } \\
\text { fragments, burnt clay }\end{array}$ & & Pedogenesis, erosion & $\begin{array}{l}\text { Colluvial with pedogenic } \\
\text { features }\end{array}$ \\
\hline F11 & $\begin{array}{l}\text { Slightly } \\
\text { organised }\end{array}$ & $\begin{array}{l}\text { Light brown } \\
\text { silt }\end{array}$ & ++ & $\begin{array}{l}\text { Charcoal, bone } \\
\text { fragments, burnt } \\
\text { clay, sherds }\end{array}$ & Runoff, reptation & Pedogenesis, erosion & $\begin{array}{l}\text { Reworked archaeological } \\
\text { level in colluvial deposits }\end{array}$ \\
\hline F12 & $\begin{array}{l}\text { Slightly } \\
\text { organised }\end{array}$ & $\begin{array}{l}\text { Yellowish } \\
\text { brown-grey } \\
\text { silt }\end{array}$ & ++++ & $\begin{array}{l}\text { Charcoal, bone } \\
\text { fragments, burnt } \\
\text { clay, sherds }\end{array}$ & & Pedogenesis, erosion & $\begin{array}{l}\text { Slightly disturbed } \\
\text { archaeological layer }\end{array}$ \\
\hline F13 & $\begin{array}{l}\text { Slightly to } \\
\text { strongly } \\
\text { organised }\end{array}$ & $\begin{array}{l}\text { Yellowish to } \\
\text { reddish silt }\end{array}$ & +++ & $\begin{array}{l}\text { Construction earth } \\
\text { slightly burnt }\end{array}$ & $\begin{array}{l}\text { Archaeological } \\
\text { structure reworked or } \\
\text { in situ }\end{array}$ & Weathering & $\begin{array}{l}\text { Mud structure or mud- } \\
\text { brick, adobe }\end{array}$ \\
\hline
\end{tabular}




\begin{tabular}{|c|c|c|c|c|c|c|c|}
\hline Type & Organisation & Sediments & $\begin{array}{l}\text { Archaeological } \\
\text { artefacts }\end{array}$ & Nature & Process of deposits & $\begin{array}{l}\text { Post-depositional } \\
\text { evolution }\end{array}$ & Interpretation \\
\hline F14 & $\begin{array}{l}\text { Slightly to } \\
\text { strongly } \\
\text { organised }\end{array}$ & Silt & ++++ & $\begin{array}{l}\text { Charcoal, } \\
\text { microcharcoal and } \\
\text { ashes }\end{array}$ & $\begin{array}{l}\text { Archaeological } \\
\text { structure reworked or } \\
\text { in situ }\end{array}$ & Weathering & $\begin{array}{l}\text { Hearth or reworked } \\
\text { hearth }\end{array}$ \\
\hline F15 & $\begin{array}{l}\text { Strongly } \\
\text { organised }\end{array}$ & Sandy silt & ++++ & & $\begin{array}{l}\text { Archaeological } \\
\text { structure in situ }\end{array}$ & $\begin{array}{l}\text { Weathering, } \\
\text { dissolution }\end{array}$ & Compacted soil \\
\hline F16 & $\begin{array}{l}\text { Strongly } \\
\text { organised }\end{array}$ & $\begin{array}{l}\text { Carbonated } \\
\text { silt }\end{array}$ & ++++ & Ashes & $\begin{array}{l}\text { Archaeological } \\
\text { structure in situ }\end{array}$ & $\begin{array}{l}\text { Weathering, } \\
\text { dissolution }\end{array}$ & Hearth \\
\hline F17 & $\begin{array}{l}\text { Strongly } \\
\text { organised }\end{array}$ & & +++++ & $\begin{array}{l}\text { Gravel, shaped } \\
\text { construction earth }\end{array}$ & $\begin{array}{l}\text { Archaeological } \\
\text { structure in situ }\end{array}$ & Weathering & $\begin{array}{l}\text { Oven or combustion } \\
\text { structure }\end{array}$ \\
\hline
\end{tabular}

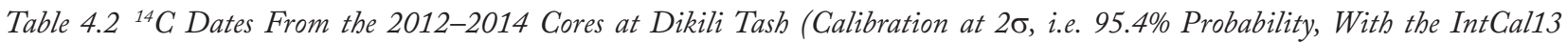
Curve). Dates from the 2010 cores have been published in Lespez et al., 2013, and reproduced in this volume (Appendix), together with those from earlier cores $A$ and $B$.

\begin{tabular}{|c|c|c|c|c|c|c|}
\hline Inv.no. & Sample & Exp. Lab.no. & Meas. Lab.no. & BP date & $\pm \mathrm{BP}$ & calBC date $(2 \sigma)$ \\
\hline \multicolumn{7}{|l|}{ Core 7} \\
\hline $1165-003$ & charcoal & Lyon-10334 & SacA-33943 & 6960 & 35 & $5971-5745$ \\
\hline \multicolumn{7}{|l|}{ Core 10} \\
\hline $9245-005$ & charcoal & Lyon-10333 & SacA-33942 & 6875 & 30 & $5841-5707$ \\
\hline $9251-002$ & charcoal & Lyon-10332 & SacA-33941 & 7030 & 35 & $5996-5842$ \\
\hline $9255-002$ & charcoal & Lyon-10331 & SacA-33940 & 7150 & 30 & $6068-5986$ \\
\hline $9262-001$ & charcoal & Lyon-10330 & SacA-33939 & 7200 & 30 & $6203-6003$ \\
\hline \multicolumn{7}{|l|}{ Core 12} \\
\hline Dik12-221 & charcoal & & Poz-65035 & 7530 & 50 & $6467-6254$ \\
\hline Dik12-233 & charcoal & & Poz-65036 & 7585 & 30 & $6475-6405$ \\
\hline
\end{tabular}

Center of Atomic Energy at Saclay (France), with the AMS method; only two samples among those of interest to us here were dated at the Radiocarbon Laboratory of Poznań (Poland), again with AMS.

The succession of the different types of sediments in each core, combined with the radiocarbon dates obtained (Table 4.2), and their correlation, taking into account the compression effect (5-20 percent), enable us to interpret the formation process of the tell settlement.

\section{INTERPRETATION OF THE RESULTS AND Consequences for Our Knowledge About the Early Neolithic In the Area Under STUdY}

The results obtained so far allow us to reconstruct the evolution of settlement at Dikili Tash in a quite detailed manner, from the end of the Last Glacial period until the advanced stages of the Neolithic.

\section{The Pristine Soil}

The original soil was reached in all drillings: it consists of a light yellow, sandy or silty sediment (F1 to
F3), whose formation dates back to the Pleistocene, on top of which developed during the early Holocene an argillaceous dark-coloured soil (F4); the latter is rich in organic materials, reflecting a slow decomposition in a forested environment (Figure 4.5). This was the soil first encountered by people that came to live at Dikili Tash, little after the mid-7th millennium вс (see below ii). Both the Pleistocene substratum and the Holocene palaeosol appear at slightly different altitudes, suggesting a gentle but clear north-west/ south-east inclination, which corresponds to the natural slope of the large Pleistocene alluvial fan underlying the site's location. Such piedmont landscapes were probably forested since the beginning of the Holocene according to the pollen data of the marsh of Philippi (Wijmstra, 1969; Greig \& Turner, 1974; Pross et al., 2009; Glais et al., 2015).

\section{Geometry of the Site and Position of the First Settlement (Figure 4.2, 6-8)}

Evidence of human activity - lithics alongside with tiny fragments of bones, amorphous burnt clay and charcoal - is present already in the topmost layers of the palaeosol in most of the intra-site cores (Lespez et al., 2013: 34-5 and Fig. 4). The date, however, of 


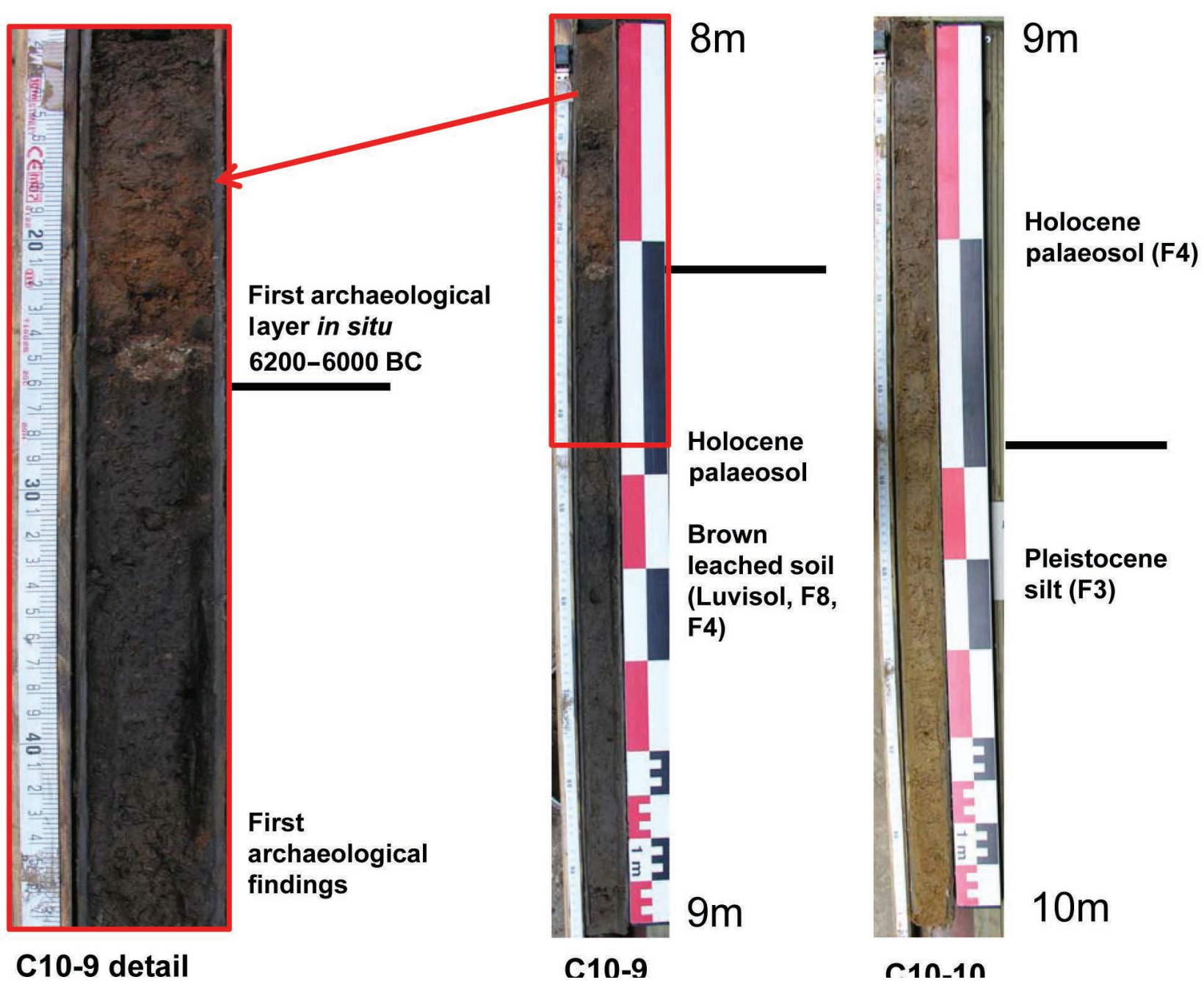

Figure 4.5. Lowest Part of Core C10, Showing the Passage From Pleistocene Silt to the First Level of Occupation on Top of the Holocene Palaeosol

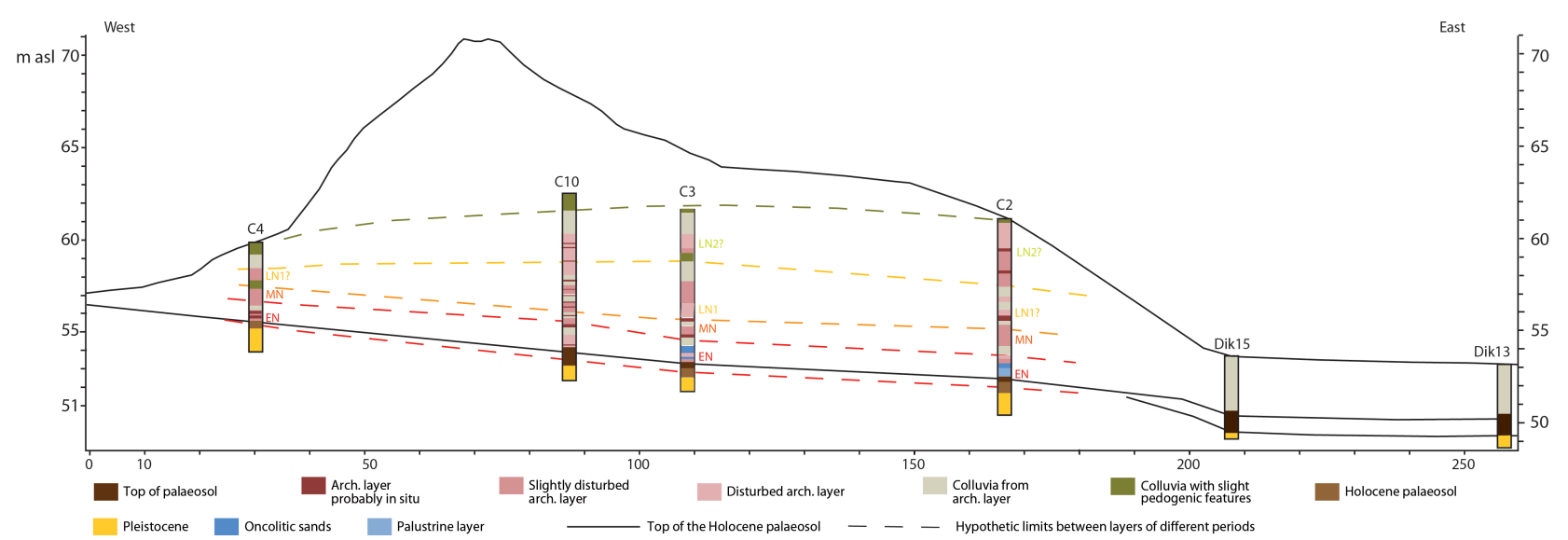

Figure 4.6. West-East Section of the Dikili Tash Tell With Presumed Evolution of the Settlement in the Different Periods. EN: Early Neolithic; MN: Middle Neolithic; LN1: Late Neolithic I; LN2: Late Neolithic II/Chalcolithic 


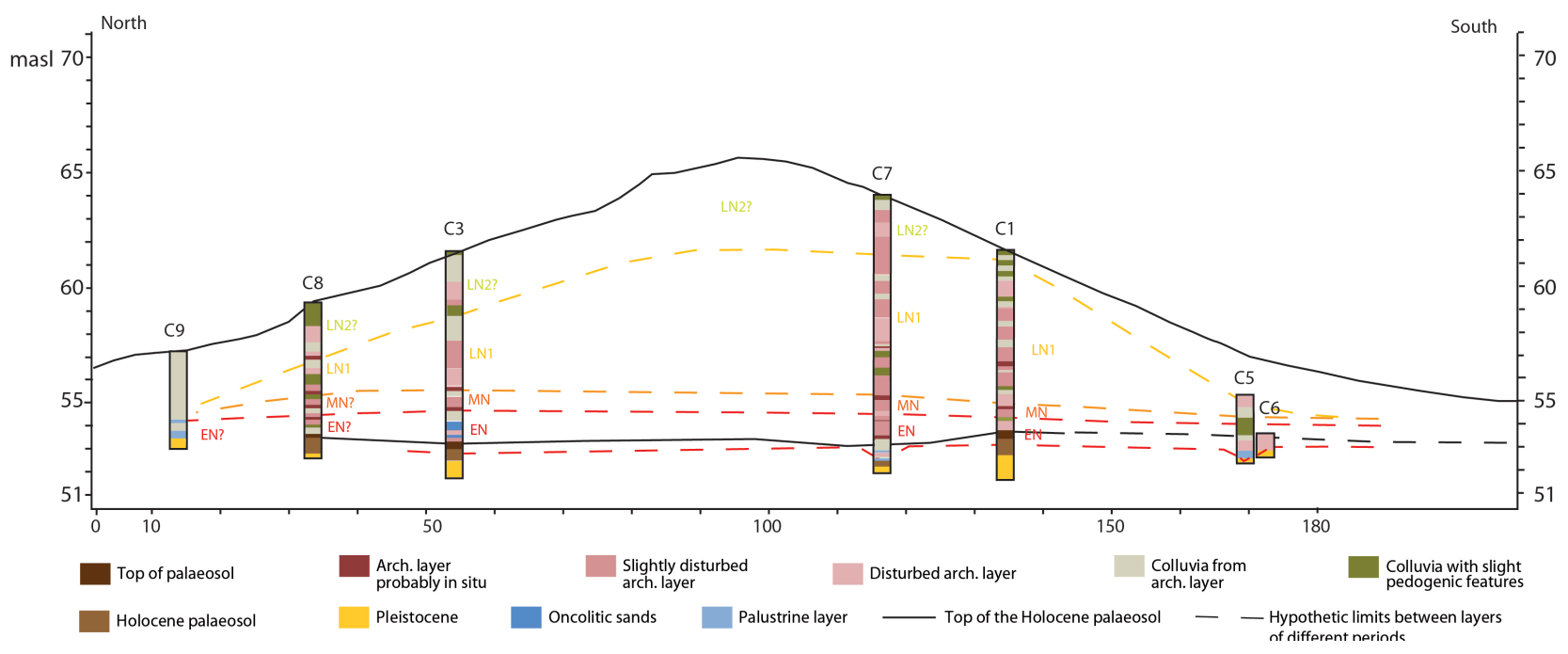

Figure 4.7. North-South Section of the Tell

these 'intrusions' is not the same everywhere: the earliest such remains are located indeed in the area of cores C2, C3 and C10, respectively in the eastern and northeastern parts of the future tell, which are also those closer to the water source. The available ${ }^{14} \mathrm{C}$ dates here are for the years around 6400/6300 cal вс, ${ }^{2}$ that is practically one thousand years before the earliest layer excavated in sector 1 , at the tell's southern slope, and more than five hundred years before the earliest radiocarbon-dated deposits in the nearby core B of 1993 (supra). In the latter area, the beginning of human activity does not seem to go beyond 6100 or $6000 \mathrm{cal} \mathrm{BC}$, as attested by a ${ }^{14} \mathrm{C}$ date from the palaeosol's top in core $\mathrm{C} 1$ (Lyon-7617). Therefore, it is not here that we should dig in order to unearth the earliest occupation remains at Dikili Tash. An even later date is obtained from the palaeosol's top in core $\mathrm{C} 4$, to the northwest, indicating that this was the last part of the site to be visited by the Neolithic settlers. It should be recalled that a date around 6500/6400 cal вС (Lyon5018) was also obtained from the Holocene palaeosol in the 1993 core A: initially left aside as an isolated poorly contextualised measurement, this date seems today perfectly coherent with the rest, indicating that the first human activities in the site developed along the eastern and northeastern foot of the present tell. Furthermore, one of the core drillings made in the offsite area at the bottom of the tell (Dik12, total depth $4 \mathrm{~m}$ ) shows the development of a marshy palaeosol, which contains archaeological artefacts (but no architectural remains) and evidence of cereal cultivation (detailed presentation in Glais et al., 2015). Its dating

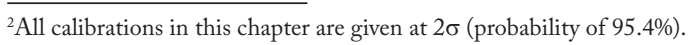

from two radiocarbon dates to the middle of the 7 th millennium BC (Poz-65035 and Poz-65036) indicates that the activities of the first settlers extended also in this area.

An occupation level in situ (F15) was found immediately on top of the palaeosol in the intra-site core $\mathrm{C} 10$ and another one, very slightly disturbed (F14), in C3. The former was rich in artefacts, especially sherds with monochrome (grey-black and reddish-brown) polished surfaces. Given the small distance between the two points, one could be tempted to assume that they belong to the same occupation episode, which would represent in this case the first settlement, properly speaking, at Dikili Tash. But the ${ }^{14} \mathrm{C}$ date from C10 is younger than the one from C3 (c.6200-6000 versus 6378-6220 cal $\mathrm{BC}$, respectively Lyon-10330 and Lyon-7630). The explanation for this discrepancy seems to lie in the history of events in this area, in connection with water: the presence of a series of layers with silts and oncolithic sands $(\mathrm{F} 5, \mathrm{~F} 6)$ at less than $50 \mathrm{~cm}$ above the palaeosol in cores $\mathrm{C} 2$ and $\mathrm{C} 3$ suggests indeed a rise of the water level in the pond formed by the spring northeast of the site, dated to c.6200-6000 cal BC (Lyon-7625, Lyon7629). The presence of marshy sediments near the base of $\mathrm{C} 8$ and $\mathrm{C} 9$ probably has to be connected with the same humid event, which would have affected these areas more severely. This incident probably stopped the development of the settlement at those precise spots, causing the inhabitants to move a few meters farther to the west, at $\mathrm{C} 10$. Building activity started again in the area of $\mathrm{C} 2$ and $\mathrm{C} 3$ only after the water level was back to normal and the area had filled with colluvia. No other events of that kind are seen in the following parts of the sequence. 


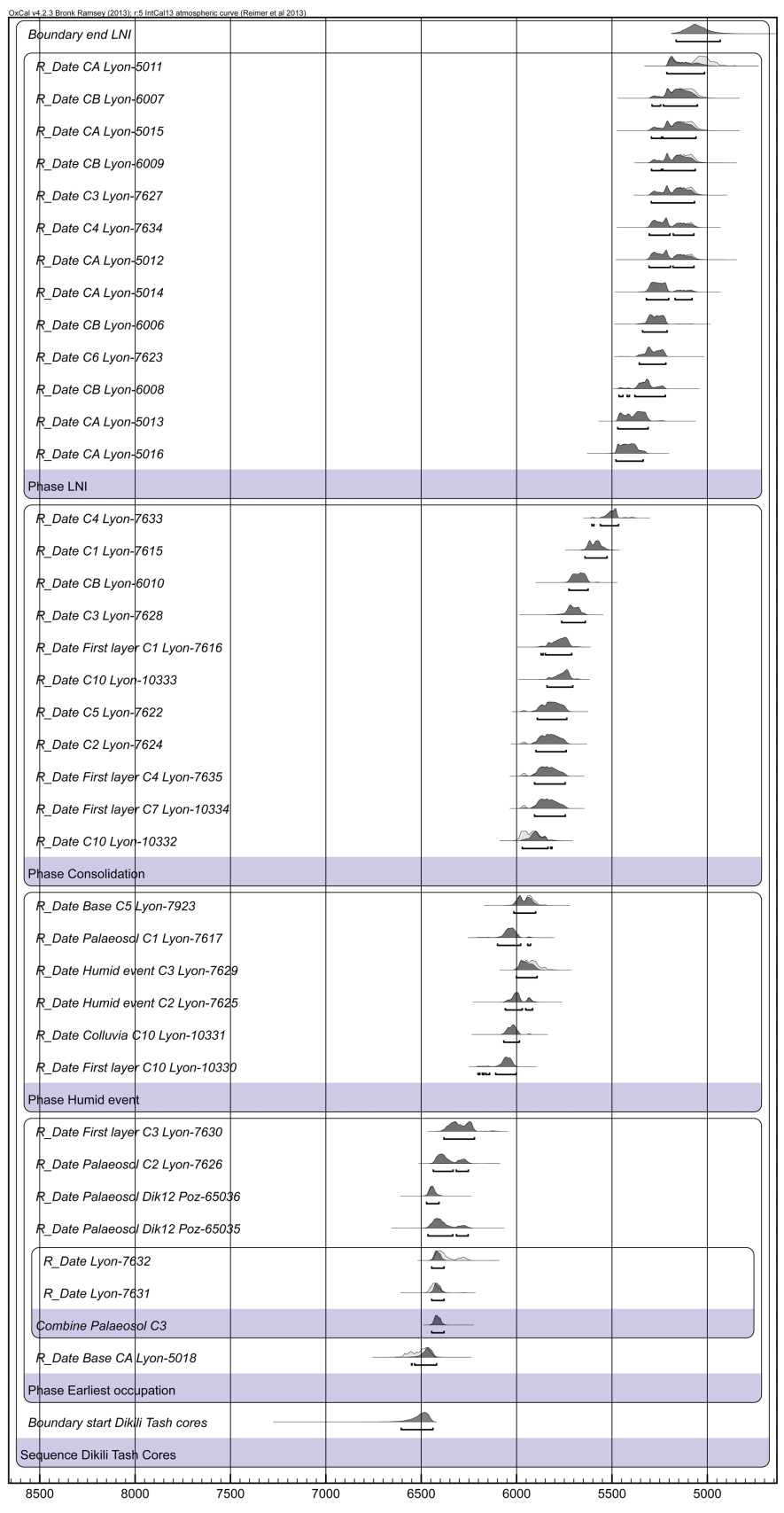

Figure 4.8. Diagram With the ${ }^{14}$ C Dates From Cores at Dikili Tash (Intra-Site and Close Off-Site), Modelled With OxCal (v4.2.3) According to Their Attribution to the Successive Occupational Stages

\section{The Settlement's Evolution During the Next Centuries}

The earliest layers in the cores taken from the other sides of the tell (C1, C7 and $\mathrm{C} 5$ to the south, $\mathrm{C} 4$ to the northwest) also date to the years after $6100 / 6000$ and 5900/5800 cal $\mathrm{BC}$, respectively, indicating a progressive expansion and at the same time a consolidation of the settlement at the onset of the 6th millennium вс. The succession of anthropogenic sediments in the different cores bear witness to the progressive construction of the tell. They show levels of occupation, abandonment and some thin layers of colluvial deposits. Nevertheless, the accumulation of anthropogenic deposits remained slow and Dikili Tash was a large flat site on the edge of a small marshy valley. The tell form was shaped in the last periods of the Neolithic, from 5400 вс onwards, through a succession of occupation levels in the same place as testified by archaeological excavations. The settlement was maintained more or less within the same limits during the rest of the 6 th millennium 
and beyond, at least until the end of the 5th millennium $\mathrm{BC}$, when it seems to have been abandoned for a few centuries (Darcque et al., 2014; Darcque et al., 2015: 410-4; Tsirtsoni, 2016).

\section{Conclusions and Perspectives}

The discovery of Early and Middle Neolithic layers at the base of the tell at Dikili Tash puts an end to the lasting debate about the start of permanent settlements in eastern Macedonia and provides interesting clues concerning the processes of establishment of the newcomers under the new conditions (topographical, environmental, etc.). However, we cannot appreciate thoroughly the role and the dynamics of these conditions until those layers are properly excavated and studied, and not just looked at through a 'keyhole'. Hence, this is in our plans for the following years.

According to the results from the cores, the best place to set the new excavation trench is the area around core $\mathrm{C} 3$, in the northeastern part of the tell: it was there, indeed, that the first practically undisturbed occupation levels were found directly on top of the Holocene palaeosol, rich in archaeological artefacts and radiocarbon-dated to $6400-6200 \mathrm{cal} \mathrm{BC}$. The semi-circular end-scraper found at this spot is reminiscent of some Anatolian Pre-Pottery Neolithic B (PPNB) examples (see Lespez et al., 2013: 34). It also has parallels among lithic assemblages of the Marmara area, namely at Pendik, Barcın, Ilıpınar and Aktopraklık (Gatsov, 2009, Fig. 49:3, 54:2; and personal information from I. Gatsov and P. Nedelcheva). Unfortunately, at this particular spot the thickness of later deposits is at least $8 \mathrm{~m}-$ meaning that we will need a heavy infrastructure and several years of excavation before getting to the base. A 'shortcut' could be offered by the close off-site core Dik12, where mid-7th millennium deposits are found at a depth of less than $3 \mathrm{~m}$ underneath later alluvial deposits. Excavation there would concern, however, only the earliest occupation settlement, and not the rest of the Early and Middle Neolithic sequence.

More generally, the results of the core-drilling program undertaken at Dikili Tash underline the benefits from a closer collaboration between archeologists and geomorphologists-sedimentologists. Such collaboration offers the possibility to reconstruct the complete geometry and history of an excavated archaeological site, to decide reliably about new areas to investigate, and to explore the archaeological potential of unexcavated sites or parts of sites. Naturally, a core-drilling program does not replace archaeological excavation (cf. Ammerman et al., 2008: 142). It remains difficult, indeed, to fully understand the sediment features due to the small quantities of material for observation, or to correlate sediments from distant drillings, as one has to constantly take into account the compression effects, the locally developed characteristics and of course the possibility of reworking. The task is even harder, when one has to deal with sedimentary units that are poor in datable material. Nevertheless, despite these difficulties, cores can securely testify earlier occupation layers hidden inside sites with thick stratification.

The methodology described presents a great potential for investigation in the area of eastern Macedonia and Thrace, with the particular characteristics of prehistoric settlements. Indeed, the experience from Dikili Tash shows that the absence of evidence for early settlements in such areas with great alluvial and/or anthropogenic sedimentation should not be taken as a fact, even when they are well investigated archaeologically. The absence of evidence is definitely not a reliable argument for the reconstruction of population movements and habitation practices in this area. In the next years we schedule a large-scale use of the method, and also a broadening of the issues treated through a multiproxy analysis, in order to investigate the presence of anthropogenic remains at different spots, to understand the process of Neolithisation on a regional scale, and to establish the interconnection of human habitation with the local environment, and the development of this relation over time.

\section{ACKNowledgements}

The research at Dikili Tash is conducted under the auspices of the French School at Athens (école française d'Athènes) and the Athens Archaeological Society (En Athinais Archaiologiki Etaireia), with additional substantial funding from the French Ministry of Foreign Affairs and the Institute for Aegean Prehistory (INSTAP). Part of the analyses in connection with the 2012-2014 core-drillings was financed by the ArcheoMed-PaleoMex research project, which is itself a component of the international project 'Mediterranean Integrated Studies at Regional and Local Scales'(MISTRALS), coordinated in France by the National Centre for Scientific Research (CNRS). We wish to thank René Treuil for his permission to refer to the 1993 work at Dikili Tash conducted under his co-direction, as well as Robert Davidson, Christine Oberlin and Georgia Kourtessi-Philippakis for their contributions to the work conducted after 2010. We are further grateful to Ivan Gatsov and Petranka Nedelcheva for pointing to us the similarities of the lithic tool from core C3 with tools from the Marmara area, and to Agathe Reingruber for her overall useful comments. 


\section{REFERENCES}

Alram-Stern, E. 1996. Die Ägäische Frübzeit, 2. Serie: For-

schungsbericht 1975-1993, 1. Band. Das Neolithikum in Griechenland mit Ausnabmevon Kreta und Zypern. Veröffentlichungen der Mykenischen Kommission Band 16. Wien: Österreichischen Akademie der Wissenschaften.

Ammerman, A.J., Efstratiou, N., Ntinou, M., Pavlopoulos, K., Gabrielli, R., Thomas, K.D. \& Mannino, M.A. 2008. Finding the Early Neolithic in Aegean Thrace: The Use of Cores. Antiquity, 82:139-50.

Andreou, S., Fotiadis, M. \& Kotsakis, K. 1996. Review of Aegean Prehistory V: The Neolithic and Bronze Age of Northern Greece. American Journal of Archaeology, 100:537-97.

Bailey, D.W. 2000. Balkan Prehistory: Exclusion, Incorporation and Identity. London, New York: Routledge.

Bintliff, J., Howard, P. \& Snodgrass, A.M. 1999. The Hidden Landscapes of Prehistoric Greece. Journal of Mediterranean Archaeology, 15:260-6.

Bocquet-Appel, J.-P., Naji, S., Vander Linden, M. \& Kozlowski, J.K. 2009. Detection of Diffusion and Contact Zones of Early Farming in Europe from the Space-Time Distribution of ${ }^{14} \mathrm{C}$ dates. Journal of Archaeological Science, 36:807-20.

Courty, M.-A. \& Fedoroff, N. 2002. Micromorphologie des sols et des sédiments archéologiques. In: J.-C. Miskovsky, dir. Géologie de la Prébistoire: méthodes, techniques, applications. Paris: Géopré, pp. 511-54.

Courty,M.-A., Goldberg, P. \& Macphail, R.-I.1989. Soils and Micromorphology in Archaeology. Cambridge: Cambridge University Press.Darcque, P. 2013. Dikili Tash, un village néolithique dans le Nord de la Grèce. Comptes Rendus de l'Académie des Inscriptions et Belles-Lettres, 51-73.

Darcque, P., Koukouli-Chryssanthaki, H., Malamidou, D. \& Tsirtsoni, Z. 2009. Rapport sur les travaux de l'École française d'Athènes en 2008: Dikili Tash. Bulletin de Correspondance Hellénique, 133:529-41.

Darcque, P., Koukouli-Chrysanthaki, H., Malamidou, D., Tsirtsoni, Z., Lespez, L. \& Germain-Vallée, C. 2014. The Impact of Environmental Changes on the Neolithic Settlement of Dikili Tash (Northern Greece). In: G. Touchais, R. Laffineur \& Fr. Rougemont, eds. Physis. L'environnement naturel et la relation homme-milieu dans le monde égéen protohistorique. Actes de la $14 \mathrm{e}$ Rencontre égéenne internationale, Paris, Institut National d'Histoire de l'Art (INHA), 11-14 décembre 2012. Aegaeum 37. Leuven/Liège: Peeters, pp. 425-9.

Darcque, P., Touchais, G. \& Treuil, R. 1990. Dikili Tash. Bulletin de Correspondance Hellénique, 114(2):877-80.

Darcque, P., Touchais, G. \& Treuil, R. 1992. Travaux de l'EFA en Grèce en 1991: Dikili Tash. Bulletin de Correspondance Hellénique, 116:715-19.

Darcque, P. \& Tsirtsoni, Z. 2010. Evidence from Dikili Tash (Eastern Macedonia, Greece) and the Tell Issue. In: S Hansen, ed. Leben auf dem Tell als soziale Praxis. Beiträge des internationalen Symposiums in Berlin vom 26-7. Februar 2007. Kolloquien zur Vor- und Frühgeschichte 14. Bonn: Rudolf Habelt, pp. 55-69.

Darcque, P., Tsirtsoni, Z., Koukouli-Chryssanthaki, H. \& Malamidou, D. 2015. New Insights to the Copper Age Economy and Chronology at the Tell Settlement of Dikili Tash (Northern Greece). In: S. Hansen, P. Raczky, A. Anders \& A. Reingruber, eds. Neolithic and Copper Age between the Carpathians and the Aegean
Sea: Chronologies and Technologies from the 6th to the 4th millennium BCE. International workshop Budapest, 30 March-1 April 2012. Archäologie in Eurasien 31. Bonn: Rudolf Habelt, pp. 403-17.

Davis, J.L. 2004. Are the Landscapes of Greek Prehistory Hidden? A Comparative Approach. In: S.E. Alcock \& J.F. Cherry, eds. Side-by-Side Survey: Comparative Regional Studies in the Mediterranean World. Oxford: Oxbow, pp. 22-35.

Demoule, J.-P. \& Perlès, C. 1993. The Greek Neolithic: A New Review. Journal of World Prehistory, 7:355-416.

Deshayes, J. 1970. Travaux de l'EFA en 1969: Dikili Tash. Bulletin de Correspondance Hellénique, 94:799-808.

Deshayes, J. 1973. Fouilles franco-helléniques en 1972: Dikili Tash. Bulletin de Correspondance Hellénique, 97:464-73.

Evans, J.D. 1971. Neolithic Knossos: The Growth of a Settlement. Proceedings of the Prehistoric Society, 37(2):95-117.

Gatsov, I. 2009. Prehistoric Chipped Stone Assemblages from Eastern Thrace and the South Marmara Region 7th 5th Mill. B.C. BAR International Series 190. Oxford: Archaeopress.

Gaul, J.H. 1948. The Neolithic Period in Bulgaria: Early Food Producing Cultures of Eastern Europe. American School of Prehistoric Research Bulletin 16. New York: American School of Prehistoric Research.

Glais, A., Lopez Saez,J.-A., Lespez, L. \& Davidson, R. 2015. Climate and Human - Environment Relationships on the Edge of the Tenaghi-Philippon Marsh (Northern Greece) during the Neolithization Process. Quaternary International. doi:10.1016/j.quaint.2015.07.032

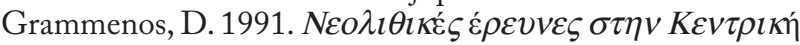

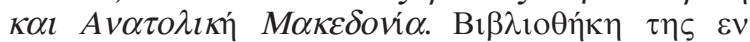

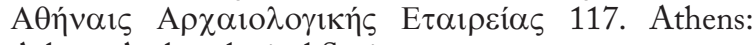
Athens Archaeological Society.

Grammenos, D. 1996. Neolithic Settlements in Macedonia and Thrace. In: G. Papathanasopoulos, ed. Neolitbic Culture in Greece. Athens: N.P. Goulandris Foundation, pp. 41-5.Grammenos, D. \& Fotiadis, M. 1980. From the Prehistoric Settlements of Eastern Macedonia. Anthropologika, 1:15-53 [in Greek].

Greig, J.R.A. \& Turner,J. 1974. Some Pollen Diagrams from Greece and Their Archaeological Significance. Journal of Archaeological Science, 1(2):177-94.

Guilaine,J.2000-2001.La diffusion de l'agriculture en Europe: une hypothèse arythmique. Zephyrus, 53-4:267-72.

Guilaine, J., coord. 2012. Les débuts du Néolithique en Europe. Dossiers de l'Archéologie, 353. Dijon: éditions Faton.

Koukouli-Chrysanthaki,H.,Malamidou,D.\&Lespez,L.2008. Cartes archéologiques de la plaine de Philippes-Drama et de ses bordures. In: H. Koukouli-Chryssanthaki \& R. Treuil, eds. Dikili Tash, village prébistorique de Macédoine orientale. Recherches franco-helléniques dirigées par la Société Archéologique d'Athènes et l'école française d'Athènes (1986-2001). Bibliothèque de la Société Archéologique d'Athènes 254. Athènes: Bibliothèque de la Société archéologique d'Athènes, pp. 395-416.

Lespez, L. 2008. L'évolution des paysages du Néolithique à la période ottomane dans la plaine de Philippes In: $\mathrm{H}$. Koukouli-Chryssanthaki \& R. Treuil, eds. Dikili Tash, village préhistorique de Macédoine orientale. Recherches franco-helléniques dirigées par la Société Archéologique d'Athènes et l'école française d'Athènes (1986-2001). Bibliothèque de la Société Archéologique d'Athènes 254. Athènes: Bibliothèque de la Société archéologique d'Athènes, pp. 21-394. 
Lespez, L., Dalongeville, R., Noirel-Shutz, C., Suc, J.-P., Koukouli-Chryssanthaki, Ch. \& Treuil, R. 2000. Les paléoenvironnements du site préhistorique de Dikili Tash (Macédoine orientale, Grèce). Bulletin de Correspondance Hellénique, 124:413-34.

Lespez, L., Tsirtsoni, Z., Darcque, P., KoukouliChryssanthaki, H., Malamidou, D., Treuil, R., Davidson, R., Kourtessi-Philippakis, G. \& Oberlin, C. 2013. The Lowest Levels at Dikili Tash, Northern Greece: A Missing Link in the Early Neolithic of Europe. Antiquity, 87:30-45.

Lespez, L., Tsirtsoni, Z., Lopez Saez, J.-A., Le Drezen, Y. Glais, A. \& Davidson, R. 2014. Beyond Determinism: A Local Approach to Nature/Society Interactions in the Southern Balkans at the Transition from the Neolithic to the Bronze Age. In: G. Arnaud-Fassetta \& N. Carcaud, eds. La géoarchéologie française au XXIe siècleFrench Geoarchaeology in the 21st Century. Paris: Éditions du CNRS, pp. 157-71.

Mee, C. \& Cavanagh, W. 2000. The Hidden Landscape in Greece: A View from Laconia and Methana. Journal of Mediterranean Archaeology, 13:102-7.

Özdogan, M. 1993. Vinča and Anatolia: A New Look at a Very Old Problem (or Redefining Vinča Culture from the perspective of Near Eastern tradition). In: J. Roodenberg, ed., Special issue on Anatolia and the Balkans: Symposium on pre-Bronze Age relations, Istanbul, November 1991. Anatolica, 19:173-93.

Özdoğan, M. 1997. The Beginning of Neolithic Economies in Southeastern Europe. Journal of European Archaeology, 5(2):1-33.

Özdoğan, M. 2011a. Archaeological Evidence on the Westward Expansion of Farming Communities from Eastern Anatolia to the Aegean and the Balkans. In: T.D. Price \& O. Bar-Yosef, eds. The Origins of Agriculture: New Data, New Ideas. Current Anthropology, 52(Supplement 4):415-30.

Özdoğan, M. 2011b. An Anatolian Perspective on the Neolithization Process in the Balkans: New Questions, New Prospects. In: R. Krauß, ed. Beginnings - New Research in the Appearance of the Neolithic between Northwest Anatolia and the Carpathian Basin: Papers of the International Workshop, 8th - 9th April 2009, Istanbul, organized by Dan Ciobotaru, Barbara Horejs and Raiko Krauß. Rahden: Marie Leidorf Verlag GmbH, pp. 23-33.

Papadopoulos, S. 2009. Questions about Neolithic Chronology in Eastern Macedonia and Thrace, Northern Greece. In: F. Draşovean, D.L. Ciobotaru \& M. Maddison, eds. Ten Years after: The Neolithic of the Balkans, as Uncovered by the Last Decade of Research. Timişoara: Editura Marineasa, pp. 49-66.

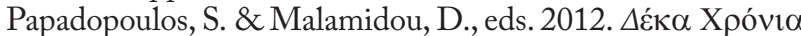

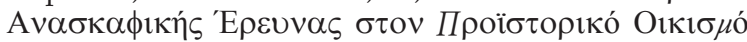

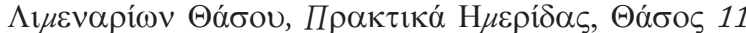
Iovגíou 2003 [Ten years of excavation research at the prehistoric settlement of Limenaria Thasos, Proceedings of the Meeting held at Thasos, 11 July 2003]. Thessaloniki: 18th Ephorate of Prehistoric and Classical Antiquities.

Perlès, C. 2001. The Early Neolithic in Greece: The First Farmers in Europe. Cambridge: Cambridge University Press.

Pross, J., Kotthoff, U., Müller, U.C., Peyron, O., Dormoy, I., Schmiedl, G., Kalaitzidis, S. \& Smith, A.M. 2009. Massive Perturbation in Terrestrial Ecosystems of the Eastern Mediterranean Region Associated with the $8.2 \mathrm{kyr}$ B.P. Climatic Event. Geology, 37:887-90.

Rasse, M. 2008. La diffusion du Néolithique en Europe (7000-5000 av. J.-C.) et sa représentation géographique. M@ppemonde, 90.

Reingruber, A. 2011. Early Neolithic Settlement Patterns and Exchange Networks in the Aegean. Documenta Praehistorica, 38:291-305.

Renfrew, C., Gimbutas, M. \& Elster, E., eds. 1986. Excavations at Sitagroi: A Prehistoric Village in Northeast Greece vol. 1. Monumenta Archeologica 13. Los Angeles: Institute of Archaeology at UCLA.

Treuil, R., ed. 1992. Dikili Tash, village préhistorique de Macédoine orientale, I. Fouilles de Jean Deshayes (1961-1975), Vol. 1. Bulletin de Correspondance Hellénique Suppl. 24. Athènes: École française d'Athènes.

Treuil, R. 2014. A Century of Research in Dikili Tash. In: E. Stefani, N. Merousis \& A. Dimoula, eds. A Century of Research in Prebistoric Macedonia, 1912-2012. International Conference Proceedings, Archaeological Museum of Thessaloniki, 22-4 November 2012. Thessaloniki: Archaeological Museum of Thessaloniki, pp. 57-65.

Treuil, R., Darcque, P., Poursat, J.-Cl. \& Touchais, G. 2008. Les civilisations égéennes du Néolithique et de l'Age du Bronze (2e édition refondue). Paris: Presses Universitaires de France.

Tsirtsoni, Z. 2016. The Late Neolithic II (Chalcolithic) Early Bronze Age Transition at the Tell of Dikili Tash. In: Z. Tsirtsoni, ed. The Human Face of Radiocarbon: Reassessing Chronology in Prehistoric Greece and Bulgaria, 5000-3000 cal Bс. Travaux de la Maison de l'Orient 69. Lyon: Maison de l'Orient et de la Méditerranée, pp. 271-97.

Van Andel, T.H. \& Runnels, C.N. 1995. The Earliest Farmers in Europe. Antiquity, 69:481-500.

Vander Linden, M. 2011. In Constant Motion? Recent Advances in Mathematical Modelling and Radiocarbon Chronology of the Neolithisation of Europe. In: A. Hadjikoumis, E. Robinson \& S. Viner, eds. The Dynamics of Neolithisation in Europe: Studies in Honour of Andrew Sherratt. Oxford: Oxbow, pp. 25-45.

Welch, F.B. 1918-1919. Macedonia: Prehistoric Pottery. Annual of the British School at Athens, 23:44-50.

Wijmstra, T.A. 1969. Palynology of the First 30 Metres of a $120 \mathrm{~m}$ Deep Section in Northern Greece. Acta Botanica Neerlandica, 18:511-27. 